\title{
IMPACT OF ReMitTANCES ON REFUgEes' Lives in CANADA: Views of SudANESE AND Vietnamese Leaders and SETtLement COUNSELLORS
}

\author{
Phyllis J. Johnson ANd Kathrin Stoll
}

\begin{abstract}
Focus groups were conducted with Sudanese and Vietnamese refugee leaders and settlement counsellors (twenty seven participants) to identify their views about the effect of sending remittances on refugees in these two communities, and their suggestions about optimizing the situation. Leaders and counsellors noted that refugees feel pride at helping out and guilt at not being able to send sufficient money. They postponed education and skills upgrades, and worked several jobs to support family here and abroad. Newcomers were advised to focus first on settling in and creating realistic expectations about their resources before sending remittances. Changes in family reunification policy were suggested.
\end{abstract}

\section{Résumé}

Des groupes de discussions ont été organisés avec les représentants des réfugiés vietnamiens et soudanais et des conseillers en établissement (vingt-sept participants) afin de connaître leur point de vue sur l'impact qu'avait sur les réfugiés leurs envois de fonds dans leurs pays d'origine, et leurs suggestions pour améliorer leur situation. Les représentants et les conseillers ont noté que les réfugiés étaient fiers de pouvoir aider leur famille financièrement ou se sentait coupable de ne pouvoir le faire. En effet, ils remettent à plus tard leur éducation et la mise à niveau de leurs compétences et prennent plusieurs emplois pour pouvoir soutenir leur famille ici et à l'étranger. On a recommandé que les nouveaux arrivants se concentrent d'abord sur leur installation et sur des objectifs financiers réalistes avant d'envoyer des fonds à leur famille. On a également suggéré des changements à la politique de réunification des familles.

\section{Introduction}

The purpose of this study is to identify Vietnamese and Sudanese leaders' and settlement counsellors' views about how sending remittances to relatives living in other countries affects the lives of refugees resettled in Vancouver, Canada. Participants were also asked for their views about the effect of family reunification policies on remittance sending, and their suggestions for educational or policy initiatives to optimize the situation.

In the extensive literature on migrants and immigrants sending remittances, the focus has been on the impact of remittances on the recipients or the recipients' country. ${ }^{1}$ Studies concerning the impact on remittance senders have looked at one refugee group each. ${ }^{2}$ This study is unusual in examining two refugee groups living in Vancouver, one of which has been settled in Canada for over thirty years (the Vietnamese) and one that has arrived in the past ten years (the Sudanese). After Toronto and Montreal, Vancouver has the largest number of immigrants in the country. ${ }^{3}$

Studies of Vietnamese refugees' economic and social adaptation have usually highlighted the early days of their resettlement, which peaked in Canada between 1979 and 1981. ${ }^{4}$ Although remittances are mentioned in some of these publications, the consequences of sending remittances to Vietnamese senders are not known. ${ }^{5}$ 
The current study builds on previous research by the first author about the adaptation of Vietnamese and Sudanese refugees. Including both groups provides an opportunity to assess the effect of remittances on documented refugees from different parts of the world who have different lengths of time in Canada, but who have experienced resettlement under some similar circumstances (e.g., Canada's refugee resettlement program, no prior ethnic community available when they arrived, and both resettling in Vancouver, Canada).

A second novel aspect of this study is that it sought the views of leaders of the refugees' ethnic communities and of settlement counsellors. Leaders have knowledge about their community that goes beyond their own experiences. Moreover, they have been involved in organizing community activities and in serving as a liaison with the agencies assisting in settlement and integration. Settlement counsellors have considerable experience and training in providing settlement assistance to newcomers to Canada. Knowing the counsellors' views of the situation and how these compare to the leaders' views provides an assessment of whether there is congruence in understanding the potential impact of remittances on refugee settlement and integration. Such congruence is important because counsellors and leaders are potentially in a position to effect educational changes and program initiatives related to refugee resettlement.

A third aspect of this study is the inclusion of questions concerning the participants' views about the effect of family reunification policies on sending remittances. The rules governing refugees' sponsorship of relatives as potential immigrants can ameliorate or exacerbate financial and other problems of resettlement and remittance, and refugee leaders and counsellors have relevant views concerning possible changes in those rules.

\section{Literature Review}

This section provides a review of the situation of Vietnamese and Sudanese in Canada: information about Canada's Refugee and Humanitarian Resettlement Program under which they were settled; the size of the communities; what is known about their remittance patterns; and a description of Canadian family class sponsorship, which is highlighted because of the decision refugees face about saving to sponsor family or continuing to send remittances to family members left behind.

Canada's Refugee Resettlement Program and Number of Vietnamese and Sudanese Resettled

The Canadian Refugee and Humanitarian Resettlement Program includes both private and government sponsors. Private sponsors are church or community groups or groups of five or more individuals who agree to assist the refugees financially for up to a year. Funds from the government through the Resettlement Assistance Program provide similar financial assistance for the government-sponsored refugees. Both types of sponsorship provide assistance with locating housing, obtaining employment, upgrading occupational training and English skills, and learning about life in Canada. The Vietnamese were the first group resettled under this system. ${ }^{6}$ Vietnamese refugee arrivals from 1979 through the 1990s and subsequent sponsorship of family members created a 2006 census count of 22,950 Vietnamese in Vancouver; all but 1,295 arrived prior to $1991 .^{7}$

The Sudanese could potentially be settled under either type of sponsorship; however, the majority was government sponsored. The private sponsorship program is no longer designated for an unnamed refugee, but is for named refugees who have been identified by relatives and by refugees already settled in Canada. ${ }^{8}$ Church and community groups were the main private sponsors. The 2006 census count was 765 Sudanese refuges, mainly Christian from Southern Sudan, in Vancouver; 60 percent arrived between 2001 and 2006, with the remainder between 1991 and $2000 .^{9}$

\section{Vietnamese as Remitters}

During their initial resettlement, meeting the obligation of supporting family in Vietnam or refugee camps was difficult for refugees with limited wages or sporadic employment. ${ }^{10}$ Many showed considerable ingenuity in sending food, clothing, medical items, and money to relatives in Vietnam during their early resettlement. ${ }^{11}$ Reasons for not sending money included being too poor, having lost contact with relatives, or parents being deceased. ${ }^{12}$

As North American trade relations with Vietnam evolved in the mid-1990s, the Vietnamese were able to return for visits, to work with Vietnamese businesses manufacturing consumer goods for export, and to serve as consultants in development projects. ${ }^{13}$ Such visits were also opportunities to provide remittances. One other pattern of remittances is that Vietnamese men go to Vietnam to choose a marital partner, and then send money to support her until sponsorship is completed. ${ }^{14}$

A World Bank study of remittance channels between Canada and Vietnam found that remittances are now primarily for special holidays, weddings, or funerals, rather than sent on a routine basis, and some are for investing in family-run businesses. The study noted that nothing is known about the consequences of such remittance behaviours for either the sender or the recipient. ${ }^{15}$ 


\section{Sudanese as Remitters}

Positive and negative effects of sending remittances to Sudan were identified by Akuei. ${ }^{16}$ Refugees were often pressured to remit money, and were overwhelmed by the expectations to send money for emergencies and ongoing living expenses. They felt anxious and guilty when they could not juggle their own expenses and those of family abroad who were in more dire financial straits than themselves. They also felt pride at sending remittances that helped maintain kinship ties. Not fulfilling their responsibility to family created distress for Sudanese in Ontario. ${ }^{17}$ In their early resettlement, Sudanese men experienced high levels of emotional and financial strain from remitting an average of $\$ 148$ per month. ${ }^{18}$

$\operatorname{Lim}^{19}$ noted that Sudanese refugees in the US gave up educational opportunities to work more hours to support family elsewhere. Others noted that financial difficulties ${ }^{20}$ and financial role strain ${ }^{21}$ had an impact on their adjustment in their new country.

Findings from two Canadian studies on remittances provide context for Vietnamese and Southern Sudanese remittance patterns. In the Longitudinal Survey of Immigrants to Canada, 21 percent of new immigrants sent money in the first two years; 29 percent at four years. Refugee and Family Class (sponsoring family) were more likely to send money than the Economic Class (skilled workers, entrepreneurs) immigrants (28 percent, 27 percent, and 23 percent, respectively). As a percentage of a remitter's family income, the rates were relatively low, 3 percent at two years and four years after arrival. Refugees experienced more of an impact on income because of their lower incomes. ${ }^{22} \mathrm{~A}$ Vancouver survey of immigrants' transnational activities found that 24 percent of refugees sent money to family in their home country. ${ }^{23}$

\section{Remittances or Family Sponsorship: A Tradeoff?}

Vietnamese and Sudanese families are extended ones, which may translate into extensive financial responsibilities for remittances or for eventually sponsoring relatives to Canada. In addition, refugees whose kinship ties may have been fragmented, with close family escaping to different countries, or whose close family members were killed, may establish closer ties with remaining relatives, even distant ones. How these family relationships are defined by immigration policy is critical in the refugees' ability to sponsor and build family support networks in their new country. If sponsorship is not possible, continuing to support these extended family relationships financially through remittances may be the refugee's only recourse. The competing demands on refugees' income include saving to qualify for sponsoring family while continuing to send remittances and supporting themselves in the new country.

Canada's immigration legislation on family sponsorship allows citizens and permanent residents who are over the age of eighteen to sponsor the following family members: (i) spouse, common-law partner, or conjugal partner; (ii) parents and grandparents; (iii) dependent children; (iv) brothers, sisters, nieces, nephews, or grandchildren under age eighteen and not married or common-law. If the refugee does not have a member in the first category, then he or she may sponsor someone from the next category, and so on. ${ }^{24}$ Proof of financial ability to sponsor is required. Sponsors must provide for basic requirements for a minimum of three years for a spouse or ten years for other relatives. ${ }^{25}$

Longitudinal data indicate that fewer than 10 percent of Vietnamese in Vancouver were able to qualify to sponsor family after four years in Canada; however, after ten years, 29 percent had sponsored, with over half of them sponsoring two or more family members. ${ }^{26}$

\section{Method}

Participants were recognized leaders who were current or past officers in their respective community associations or leaders serving as liaisons with settlement agencies. A published listing of Vietnamese associations and agencies serving Vietnamese was the source used to identify and recruit Vietnamese participants. The Southern Sudanese Association was the source of male leaders; female leaders were recruited from those women who had served as liaisons with the settlement agencies. Settlement counsellors who had worked with African refugees, in particular those from Southern Sudan, were recruited from the major settlement agencies.

A consultant who had worked with immigrants was hired to organize and conduct the focus groups, with the assistance of the second author, who was similarly trained. The questions covered three areas: (1) remittance practices used by members of the community, (2) the effect of sending remittances on individuals and families, and (3) the effect of family reunification policy on remittance sending, and potential educational or policy initiatives to optimize the situation.

Focus groups were chosen to stimulate discussion that might not have been possible with individual interviews. There were seven focus groups: two for Vietnamese (one with two women; one with three women and two men), two for Sudanese women (one with two and one with five women), one for Sudanese men (five men), and two (four people each) of settlement counsellors. To facilitate participation, settlement counsellors suggested separate focus groups for Sudanese, but not Vietnamese, men and women. 
Vietnamese female leaders were more interested in participating than male leaders; Sudanese men and women were equally interested. A male Vietnamese leader who was also a settlement counsellor but not a participant in the study read through a summary report of the findings to provide an additional assessment of the Vietnamese remittance situation. He made editorial but not substantive changes to the report.

Focus groups were in English, took place after work or on weekends, and were held in a local community meeting room. Participants received a $\$ 25$ honorarium. The sessions lasted 1.5 to 2.5 hours, with more time spent by the Sudanese than the Vietnamese participants. The sessions were audio recorded and transcribed by a professional transcriptionist.

Open coding, followed by categorizing, was done for each set of questions and participant group; comparisons of themes across groups were then completed ${ }^{27}$ Comparisons were between Vietnamese and Sudanese in their early years of resettlement, male and female leaders within each refugee group, and leaders' and settlement counsellors' views.

\section{Findings}

Participants' Views about the Sender's Perspective on Remittance Sending

The leaders and settlement counsellors discussed remittance practices, noting potential effects on the sender and how refugees coped with meeting the needs of family members in Canada and overseas. The leaders in both communities said that sending remittances was a very common practice and members of their communities soon learned that it was too expensive to send goods so they focused on sending money. The leaders also noted that remittances are viewed as an obligation, that meeting the obligation has consequences for the remitters, and that refugees develop strategies for coping with the obligation.

\section{Remittances are an obligation}

Remittances are a necessity rather than a choice, at least initially. "Obligation" has multiple meanings, including an urgent need, reciprocation for past help received, and cultural views regarding familial support.

The Sudanese leaders noted that family overseas have a desperate need for remittances for their survival. As stated by one female leader, "We have to send money because where we come from people are suffering so they need help from us... ." Money sent often addresses the most urgent situation, not the support of a specific close family member if the need is greater for a distant relative or friend overseas.

The male Sudanese leaders gave examples of the pressure to meet financial obligations. "[T]hey kind of send a message to us-we need your help financially-you have to contribute-you find that to be an obligation." If they do not answer a phone request for remittances, the overseas relatives say on the voice mail, "We know you are there-you don't want to answer."

As conditions improve for the family remaining in Vietnam, the meaning of obligation has less urgency and reflects primarily traditional cultural expectations. The Vietnamese leaders noted that in contrast to the early days of their resettlement, sending remittances was no longer urgent because relatives in Vietnam are not poor and goods are available for purchase more cheaply there than they are in Canada. However, there are circumstances based on traditional customs and filial piety when remittances would be sent, and obligation, regardless of need, would be the basis for the remittances. A Vietnamese leader said, "You are obliged to send, especially during the [lunar] New Year. If your parents are alive you will [send] no matter how rich they are."

While the urgency of the remittance obligation may decrease with time, most of the settlement counsellors did not think that the practice would ever stop. Reasons for continuation were that there may not be enough work in the home country, wars create an urgent need for support of family, and sponsorship of family has not been completed, especially for the more recently arrived refugees. Another ongoing reason is the desire to locate a spouse from one's own culture, which requires remittances to a wife until sponsorship is completed.

\section{Impact on the sender of remittances}

The leaders and settlement counsellors identified effects on the remitters of carrying out the obligation of remittance sending. These effects included reduced money for living expenses in Canada; working multiple, low-wage jobs; postponement of their own skill or language upgrades in order to send money; conflicts in family relations; and guilt or pride, depending upon whether the obligations were met.

According to the Vietnamese leaders, sending remittances affected families "quite a bit" in the early days of their resettlement. In particular, they did not have a break from work, or worked several jobs, which meant that there was no time for school, for improving English, or getting their job qualifications recognized. In essence, a chance for a well-paying job was less likely because of the urgent need to get employment to support themselves and their families elsewhere. Similar negative effects were identified by male but not female Sudanese leaders. The male leaders also noted that needs of family in Canada were not being met and funds were not being saved for future education of the children. Thus, development, or recognition, of their skills 
and education was postponed or not done as the money was needed for remittances.

For both groups of refugees, accumulation of financial resources was not possible in the early days of their resettlement; this was due to sending remittances and to having a low income, both during their time as a sponsored refugee and as an entry level employee in low-wage work. In speaking about Sudanese refugees, a settlement counsellor gave this example of the effects of sending remittances on their inability to increase their financial resources:

They send money regularly and this puts financial pressure on them, such as can't afford to buy a house ... and then you don't have any help to just cover the hole because you keep sendingand you have also other commitment here-you have to live-you have to eat-you have to feed your kids or your loved one and your commitment to your community and the other end you're sending the money again in the other country so-you will be poor every day.

An example of long-term effects of sending remittances was given by a Vietnamese leader who described the impact on an eldest son who continued to carry out the traditional obligation to support his extended family here and overseas. He earned a good wage but had had financial difficulties because of his continuing remittance obligations. In comparison to others who arrived in Canada at the same time, he had neither become a homeowner nor did he have a newer model car.

Meeting the remittance obligation was exacerbated by the disconnection between the perceptions of those overseas about the resettled refugees' finances and the reality of the refugees' finances. The perception that those settled in Western countries had money overshadowed the refugees' explanations of any difficulties they might have in sending money. We labelled this a "mirage of financial resources." In talking about family in Sudan and neighbouring countries, a female Sudanese leader said,

They have [the] idea that people who come here they have money. They don't even know what's going on for you-maybe your child needs a dental treatment or-that costs a lot of money so-do they ever ask you how you're doing here and how things are going. Well they ask but it doesn't really make it any different like if you even try to explain that we are struggling here too-that doesn't really count in their minds.

A settlement counsellor gave an example of why some refugees send more remittances than they can afford, reinforcing this "mirage of resources." A mother of six children sent $\$ 500$ and then did not have enough to live on for the rest of the month. Her solution was to go to a settlement counsellor to borrow money. The client said, "At least here I can go back to immigration or whatever and I can borrow more but back home there's nowhere they can get the money."

Refugees' memories of what life was like in the home country, and how they themselves had reacted to family members not sending them sufficient remittances, reinforced feelings of guilt at not meeting those expectations. The male Sudanese leaders provided examples of the quandary refugees faced when they could not meet the expectations and did not want to let their relatives down: "We don't want to kill their hopes-we are the hope-so if this person is sick and relying on you and if you say completely no-his hope is going to die."

Meeting the obligation, that is, sending money to family, fostered additional family members seeking some financial help, as described by a settlement counsellor:

[Y]ou start sending money just to your mom-or to your sistershe start dressing up-somehow-people start seeing her getting better-and other relatives will start emailing you-phoning you-writing you letter-so you end up having a kind of customership you know in the family.

Female Sudanese leaders highlighted problems remittance sending created in family relationships, including divorce. The Sudanese male leaders talked about how arguments and misunderstanding between the spouses might occur in deciding which relatives would be sent remittances. The Vietnamese leaders noted that over time sending remittances has created conflicts between spouses and between parents and children. Conflicts occurred in deciding which side of the family received the remittances, whether the person making the money had control over who would receive the remittances, and whether the money was for family in Canada or in Vietnam. In some instances, a spouse sent money to his or her family secretly, which was upsetting to the other spouse, who felt that the money should be sent to both sides of the family.

Recognizing that family conflicts might have arisen about equity in sending money, the Sudanese and Vietnamese leaders also noted that sending remittances was one way to keep the family connected. In the words of a male Sudanese leader,

We try to protect our family tree-so like you send to your mother and then you send to your father or you just send to somebody from your mother's side or somebody from your father's side and also you send to someone from your wife's side-you know both sides too-so you know that keeps all this family coming together. 
Although the leaders emphasized that meeting the obligation was important, they also expressed the concerns that refugees have about recipients becoming dependent on continued financial support. The Vietnamese leaders gave several examples that showed how upset the refugees, who had worked hard to send the money, felt when they visited relatives in Vietnam and saw how the recipients lived and used the money they had received. The settlement counsellors noted that the money received was not sufficient to set up a business, but was enough to live on. Because the people knew the money was coming regularly, they did not get a job, but remained dependent on the remittances.

Dependency on remittances was not an issue for the Sudanese, as they understood the need for remittances for immediate survival and they were not yet at a point of discussing longer-term dependency. Settlement counsellors cautioned that war zones are different and that people residing in those areas cannot really seek a job but remain dependent on support from elsewhere; thus, reinforcing remittances are an urgent need.

The Sudanese male leaders were concerned that the focus on working hard to meet the remittance obligation might have a negative impact on the development of the Southern Sudanese community. Because community members were working many hours, they had less time to organize and attend cultural events. Such events were viewed as important in developing a sense of community to teach their children about their heritage and to contribute to the needs of Sudanese here and overseas. Similar concerns were not expressed by the Vietnamese leaders.

All of the focus groups noted that the refugees felt proud that they could help out by meeting their remittance obligations, that they slept well knowing they had taken care of their family members, and that they were pleased that their remittances had had a positive impact on the recipients. Sudanese leaders said the remittances delivered the recipients from debt, provided them with basic living expenses which were necessary given that their wages had not been paid for several months, and paid for their educational fees. Vietnamese leaders identified a number of positive effects on the recipients because of the outside financial help: chances to renovate or buy houses, to run a business, to get an education, to get medical care, and to raise their children. They noted that recipients are proud of how they have done in comparison to others in Vietnam, and know that their success was not possible without the remittances. Knowing that their remittances had helped the recipients in so many ways reinforced the senders' feeling good about meeting the obligation.

\section{Coping with the remittance obligation}

The Sudanese, but not the Vietnamese, leaders provided a number of examples of how members of their communities dealt with the obligation to send remittances. The strategies were primarily financial, but also included a reliance on cultural strengths.

The main financial strategy was getting a job with adequate wages to support relatives overseas. The leaders noted that refugees' current minimum wage work was not sufficient to meet remittance obligations and their own living expenses. As well, their savings accounts were bare and they no longer had a good credit rating. The remaining source of finances for an emergency was their friends. Thus the Sudanese had "a credit union among us" that did not have set payback periods, but commitment to repay was honoured. The female leaders noted the strategy of women pooling their finances and rotating which person's family would receive the remittance that month. This system provided more money than individual contributions, but at less frequent intervals.

Spirituality was evident as a coping mechanism to handle the circumstances they and their relatives overseas were facing. A male leader said, "We believe in God ... He will change the [plan] one day and that keeps us moving you know." A female leader said, "We are not here without purpose-and I know in my heart that there's to be a time that everything will be okay--and especially for those [in] the places where we came."

Another male leader identified the cultural value of sharing as a basis for dealing with the remittance obligation:

[W]ell it's part of our nation because sharing is one of the privilege[s] that we believe in-whether you have plenty or you are in need-you have to share with your friend or family or whatever-because every-every human you know need another human -if we share the least we have I think we feel that we have reached for perfection-yeah-so it's not a matter of how much we get but how little we get and how we share [it].

Additional cultural strengths of humour and resilience were highlighted by other male leaders: "[T]hen there is our ties together as people-we talk to each other-we joke about everything-about the situation" and "Sudanese are very resistant to difficult situations-maybe based on history."

\section{Remittances and Family Sponsorship: Ways to Optimize the Situation}

Participants discussed ways to optimize the situation of handling the remittance obligation. They also identified issues with current family sponsorship policy and suggested 
initiatives to address those issues to help refugees achieve family sponsorship.

\section{Advice about meeting remittance obligations}

The leaders' practical advice emphasized creating realistic expectations for refugees and their overseas relatives about the amount of remittances possible, focusing on settling in first before sending remittances and on budgeting for remittances.

The Vietnamese leaders suggested that newly arrived refugees should be sincere about their situation, e.g., that they are not doing well and cannot afford to send money or at least not at the level that relatives overseas might expect. This advice came from what they had observed in their early years in Canada: some Vietnamese felt they needed to say, "I am doing well here. I can buy a lot of things and things are wonderful here," even though they were struggling to send money while supporting family in Canada. The Sudanese male leaders in highlighting the juggling act refugees have between their dreams for life in Canada and their desire to support people back home also suggested presenting a realistic picture of the situation for newcomers: "The advice that I would give them - they have to drop their highest expectations - they have to live reality and they have to adjust to the reality of where they are now."

Both Sudanese and Vietnamese leaders said that newcomers should focus on getting settled first, rather than getting a job right away to send money. Settling in meant that they would have time to use wisely Canada's refugee resettlement program's provisions for education, language, and other skill upgrades. With the additional training and knowledge gained, they would be able to get a job that would support their family better in Canada and overseas.

Vietnamese leaders' advice to newcomers was to budget their money carefully in order to meet their needs and to send remittances. This is important because the newcomers may not have a good grasp of the costs of living in the new country, or how far the settlement assistance or entrylevel earnings will go to support family here and abroad. As well, the Sudanese female leaders cautioned newcomers not to assume that the initial large amount of money received upon arrival for settlement purposes (e.g., rental deposits, purchasing household and personal items, etc.) would continue to be paid out on a monthly basis. A male Sudanese leader gave specific advice on how to send remittances so that the monthly amount was not too great and allowed for the refugees meeting their own needs, as well as emergencies for relatives overseas. He said:

Don't send at the same time-if you send to your uncle-at the same time don't send to your brother-leave another month for yourself here ... don't send money end of the month ... because you'll find yourself not paying your rent-so you're going to be kicked out of the house.

\section{Family sponsorship issues}

In discussing current family reunification policy, the leaders noted difficulties in carrying out family sponsorship, in sponsoring the relatives refugees wanted rather than the priority established in the policy, and in meeting the financial obligations to qualify for sponsorship.

Evident in the discussions were transnational issues, with difficulties arising from regulations in the home county as well as in the receiving country. For example, the leaders identified instances of family members applying to leave Vietnam and being denied because the Vietnamese government blocked their exit. From the Canadian perspective, the Vietnamese leaders told stories of refugees applying to sponsor family but not being eligible to sponsor that particular relative, and emphasized the long time (e.g., several years) it took to obtain authorization for the sponsored relative to come to Canada. The Sudanese leaders gave examples of extended family members who had applied to the Canadian commission to come to Canada but were rejected. At the time of this study, the Canadian government was not bringing in sponsored refugees from Southern Sudan, and most of the local residents were not earning enough to sponsor relatives. As a result, the leaders remembered only a few in their community who finally succeeded in family sponsorship after eight or nine years in Canada. Their recourse has been to turn to church groups, who have assisted in sponsoring their relatives. Their Sudanese Association has been given the authority to be a sponsoring organization. The first person they had tried to sponsor had been turned down by the Canadian embassy in Cairo and they were discouraged about trying to sponsor others.

A major concern expressed by all of the participants was that Canadian immigration policy on family sponsorship uses a narrow definition of family, when an extended family definition is more appropriate for their culture. The Sudanese leaders talked extensively about how family members reacted when they explained that they could not sponsor them. The relatives wanting to be sponsored thought that their Canadian-based relatives just did not want to sponsor them, not that they were not able to sponsor them, given the official priority for sponsorship. As a result, there was tension between family in Canada and Sudan and between specific family members within each country.

Regulations on sponsorship also made it difficult for refugees to take responsibility for relatives who would traditionally be under their care. For example, in Sudan, if a 
man was widowed, his sister-in-law might raise the children. However, if the sister-in-law was in Canada and wanted to sponsor the children, they would be excluded from sponsorship because they have a father to provide for them. As a result, she could not fulfill her obligation to her extended family.

The Sudanese leaders said that the number of years refugees would be financially responsible for sponsored family members was not a major problem. However, they were concerned about members of the community meeting the financial requirement to qualify to sponsor, which made it easier to support elderly family abroad than to sponsor them. The male leaders said, "If we take care of them at home [with remittances]-why can't we take care of them once they are here with us." The Vietnamese did not provide information on this issue; sponsorship was no longer a current issue for them.

Suggested policy initiatives. The leaders and counsellors identified an expanded definition of family as their main policy initiative. The Sudanese leaders clarified this by saying Sudanese refugees wanted to sponsor relatives such as brothers and cousins, who could get employment; together they could support their extended families overseas or have the financial ability to sponsor them.

The Vietnamese leaders thought that making it easier to visit Canada would create less tension for refugee newcomers. Two situations that had made getting visitors' visas difficult were: (1) relatives overstaying their visas, which then made getting a visitor's visa more difficult for subsequent legitimate visitors, and (2) relatives could not come on a visitor's visa while their sponsorship application was under consideration. Temporary work visas were also suggested. They could legally work in Canada for a specified time, provide for themselves, and also help ease the burden of sending money to relatives overseas.

The female Sudanese leaders wanted the Canadian government to know the pressures that sending money created on their lives in Canada, and that a large quantity of money was sent to support extended family elsewhere. Because having dependents in Canada brings income tax breaks, they thought support of dependents elsewhere should qualify for a tax break.

\section{Discussion}

The leaders and settlement counsellors presented their views about Sudanese and Vietnamese refugee remittance practices and the impact of sending remittances on the remitter. A comparison of the leaders' and counsellors' views about the experiences of a more established group of refugees (the Vietnamese) with those of a more recently arrived group (the Sudanese) allows us to examine changes in remittance patterns over time. While the need for remittances is great in the first few years of resettlement due to the political situation in the home country, this need should diminish as the home country becomes more stable politically and economically. Much of the discussion during the Vietnamese focus groups centred on past remittance practices, when the political situation in their home country was more unstable and relatives relied heavily on money sent from abroad. Over thirty years later, the Vietnamese are still sending money, not because there is a dire need, but because cultural norms prescribe that money is sent for holidays and filial responsibilities.

Sudanese refugees, who have a short history in Canada, provide evidence of the strain-emotional and financialthat refugees face when they are safe and have their basic daily living needs met, but have little left over to send to family to help them reach safety or to provide for their needs. The early years for both refugee groups show a constant balancing act between expectations, of the refugee and of family members back home, and the reality of limited financial resources. A situation of potential "lost opportunities" emerges if refugee newcomers opt for early low-wage employment in order to support family elsewhere rather than taking the advice of leaders to settle in and take advantage of language, education, or employment training in Canada's resettlement program. Findings from two recent qualitative studies with Sudanese refugees in the United States and Australia show the negative effect of financial obligations to family back home on educational advancement $^{28}$ and adjustment. ${ }^{29}$

The similarity of Vietnamese and Sudanese remittance patterns and views about sending remittances in the early years provides some evidence that the longer-term experiences of the Vietnamese may be reflective of the future situation of the Sudanese refugees. If so, the obligation to remit money, the desperate and urgent need for money, guilt at not meeting obligations, family conflicts about equity in sending money, and the financial struggle associated with the remittance obligation will be less evident, and remittances will be for special events rather than on a regular basis. This scenario is likely if the financial situation has improved for those in Southern Sudan, as well as in Canada, and the prolonged Sudanese conflict abates. However, if wars continue and family members are not sponsored to safety, the need for remittances will continue for years to come.

Unrealistic expectations about remittances on the part of both relatives and remitters are a concern. Relatives not only anticipate that the refugees are better off financially than they are, "a mirage of financial resources," they also do not believe any statements to the contrary. The refugees also have high expectations about their need to meet all of the 
remittance obligations. Leaders advised newcomers to lower those expectations. Incoming refugees might benefit from a discussion during their orientation sessions about remittances, set within the context of settlement funds/entry level wages and cost of living in Canada. Such information could be made available on web sites through testimonials of the experiences of others, and/or through discussion groups with refugees who have had several years of experience in Canada.

One effect on senders that the leaders and counsellors identified that has not been highlighted in previous research with these groups is the family conflicts that occurred when remittances were sent too frequently at the expense of family needs in Canada, or were not sent equitably to both sides of the family. Thus, an act that kept family connected, which had a positive effect for the remitters, also created conflicts for them. Additional research is needed to identify the conditions under which remittances are viewed as keeping the family together or potentially pulling it apart.

Coping with the necessity as well as the obligation to send remittances was particularly salient for the Sudanese refugees, whose leaders provided insight on how refugees dealt with the potential stress. Sudanese cultural strengths, including a sense of sharing, spirituality, and humour were emphasized. These have been described as core Southern Sudanese values in the social science literature. ${ }^{30}$ Settlement counsellors and leaders of other newly arrived refugee groups need to identify and build on specific cultural strengths in helping newcomers to deal with the necessary obligation of sending remittances.

Similar to the Sudanese male leaders, the female leaders described the obligation to remit money, the lack of financial resources to remit enough money, reliance on friends for financing remittances, and the positive effects of remitting, such as supporting sick and aging relatives and funding the education of children. They agreed with the men that the remittance obligation was stressful, as relatives back home were suffering, desperately relied on the remittances, and did not understand the financial struggles of resettled refugees. As well, both male and female leaders identified family conflicts about sending remittances.

Gender differences among the Sudanese seem to reflect traditional roles of men as providers and women as the managers of home and family. The male but not female leaders talked about working several jobs, not having time for courses to improve their English or job skills, having used up their savings and credit, and not having time to participate in community activities. Male leaders spoke more than female leaders about systemic inequities and inadequate refugee policies. It should be noted that life circumstances in Canada led to changes in traditional roles: for example, the majority of female leaders were single parents who described the situation of women in the community in similar circumstances. As such, they were "providers" responsible for supporting family in Canada and elsewhere from their employment or social assistance income.

Family reunification policy and remittances are clearly intertwined, especially in the early years. Refugees seem to have difficulty in earning sufficient income to support family here and elsewhere while saving to sponsor family to Canada. Given that social support is helpful in the adjustment of newcomers, ${ }^{31}$ identification of workable strategies for fostering family sponsorship are needed. While encouraging the group's refugee association to sponsor relatives is one option, and has occurred for the Sudanese, it is likely to be difficult for such associations to have sufficient financial capability on their own. Unless churches or non-profit organizations can assist the associations financially, it is unlikely that the refugee associations can amass the amount of money needed to meet the community's sponsorship needs.

Two existing policy provisions were not in existence during Vietnamese resettlement, and have not met the sponsorship needs of the Sudanese. One is the "named refugee" opportunity for private sponsorship groups, in which vulnerable refugees named by refugee relatives in Canada can be sponsored, and the "one year window of opportunity" for sponsoring non-accompanying family members without meeting the financial requirements. ${ }^{32}$ The refugees may not know where their relative is, having been separated from them during their flight from conflict; they may not realize that they need to identify relatives within one year; and they may identify extended family, such as adult children or cousins, or relatives who for some other reason, do not qualify as non-accompanying family members. Settlement counsellors also alluded to the fact that these two policies are not well-known among refugee groups. They believed that the "one year window of opportunity" should be extended indefinitely for a refugee's spouse and dependent children. Additional effort to inform refugees and their leaders about the actual policies seems warranted, either through the orientations offered by settlement agencies or by programs offered by the refugee associations. Information needs to be provided more than once during the resettlement assistance period as this is one of numerous important issues covered during the initial resettlement.

Vietnamese leaders mentioned difficulties in relatives obtaining visitors' visas and not being able to visit while their sponsorship to Canada was being considered. Recent changes to Canadian immigration policy allow parents and grandparents to apply for expedited and extended visitors' visas, with which they can stay twenty-four months for each 
visit. If permanent relocation to Canada is not the goal, such visas should be helpful for participating in important family events. Reducing the wait times for family sponsorship has been a continuing problem. With the advent of extended visitors' visas, application to sponsor parents and grandparents is closed for two years; the hope is that the backlog for other applicants will be reduced. ${ }^{33}$ Whether sponsorship or extended visas for parents and grandparents are preferred by refugees is an area for future research. Factors affecting preferences may be the political and economic vulnerability of those family members.

One issue on which all of the leaders and counsellors agreed was that the definition of family in Canada's family sponsorship policy is not sufficiently inclusive for Sudanese and Vietnamese extended families. However, expanding the definition of family without changing the order of priority for sponsorship may not meet the need of refugees who want to sponsor relatives, such as a sibling who can get employment and help support the extended family abroad. As well, the "one year window of opportunity" for refugees' sponsorship of family uses the same definition of family.

Continued family separation rather than unification seems to be fostered because of the mismatch between refugees' and the government's definitions of family. ${ }^{34}$ Rather than changing the definition of family or order of sponsorship, changes in Canadian immigration policy have focused on extended visas, possibly as an alternative to sponsoring parents and grandparents. Given that refugees' spouses and dependent children could be sponsored under the one year criterion, and without having to meet the financial requirement, refugees could save to sponsor another family member. Some policy consideration should be given to their wishes and knowledge about which relative might be the most helpful in supporting family. Tax recognition for remittance obligations is not likely to be included in taxation law, as national rather than transnational boundaries determine income tax deductions for dependents. Others have suggested that if a policy could be established between the countries to verify that dependent parents were being supported, Canada might grant a tax credit for such assistance. ${ }^{35}$

The leaders and settlement counsellors provided examples that were based on their own experiences with their respective refugee communities. Their views were very similar about remittances and family sponsorship issues, and are consistent with the limited available literature about the impact of remittances on refugees. Such demonstrated congruence in knowledge is useful for effecting orientation sessions about refugees' remittances and family sponsorship.

A limitation of our study is the small number of Vietnamese focus group participants. Fewer Vietnamese men and women participated in the study compared to Sudanese men and women, most likely because they did not regard remittances as an urgent problem in their community. In addition, it was difficult to assess the effect of sending remittances on women versus men due to the relatively small sample size.

This study has focused on two refugee groups settled in Vancouver approximately twenty years apart. Our findings can be placed in a broader perspective of remittance obligations for other financially stressed refugee and immigrant groups in Canada. For example, Kosovar refugees made sacrifices in their own consumption to have some money to send to family whose needs they viewed as more urgent than their own. ${ }^{36}$ Guatemalan refugees were stressed by trying to meet financial obligations to their family, feeling pulled between survival for their family in Canada and financial help to extended family in Guatemala. Low incomes, high living costs in Canada, and high costs of making transnational connections (visits, phone calls, and remittances) resulted in the refugees becoming isolated from their extended family in Guatemala. ${ }^{37}$ Caribbean immigrants have a strong commitment to financial support to family elsewhere. Such support continues because of close transnational ties of affection and obligation. Recipients also reinforce that such support is important and appreciated. ${ }^{38}$ Simmons summarized the importance of remittances in the transnational cultural and family lives of immigrants and refugees. ${ }^{39}$ The themes identified and discussed with the Vietnamese and Sudanese refugees in the current study appear to be relevant for other refugee and immigrant groups experiencing strong remittance obligations coupled with limited or strained financial circumstances.

\section{Conclusion}

For political refugees, reaching a safe country is the beginning of the journey to reduce their family's political vulnerability. Because the refugee is now safe, his or her situation, regardless of resettlement difficulties, always appears to be better than that of those left behind. Knowing that remittances are of considerable help reinforces that this is an important ongoing obligation. The feasibility of sponsoring family, given the legal financial requirements and definition of family, are continuing concerns for refugees, especially when family members remain in a politically unstable situation. There is room for improving existing immigration and sponsorship policies to reduce financial and psychological strain on refugees who are expected to remit money. Education about policy provisions available to facilitate visits and achieve sponsorship is necessary. As well, orientation sessions for refugees would benefit from including the advice of leaders and counsellors on how to 
handle the remittance obligation while adjusting to life in the new country.

\section{Notes}

1. Ismail Ahmed, "Remittances and Their Economic Impact in Post-war Somaliland," Disasters 24 (2000): 380-389; Bimal Ghosh, Migrants' Remittances and Development: Myths, Rhetoric and Realities (Geneva: International Organization for Migration, 2006); Nicholas Glytsos, "Determinants and Effects of Migrant Remittances," in International Migration: Trends, Policies and Economic Impact, ed. S. Djajic (New York: Routledge, 2001), 253-272; Oded Stark and Robert Lucas, "Migration, Remittances, and the Family," Economic Development and Cultural Change 36 (1988): 465-481.

2. Stephanie Riak Akuei, Remittances as Unforeseen Burdens: Considering Displacement Family and Resettlement Contexts in Refugee Livelihood and Well Being. Is There Anything States or Organizations Can Do? accessed September 20, 2004, http://www.unhcr.ch/chi bin/texis/vtx/home/; Phyllis Johnson and Kathrin Stoll, "Remittance Patterns of Southern Sudanese Refugee Men: Enacting the Global Breadwinner Role," Family Relations 57 (2008): 431-443; Soh-Leong Lim, "Loss of Connections is Death': Transnational Family Ties among Sudanese Refugee Families Resettling in the United States," Journal of Cross-Cultural Psychology 40 (2009): 1028-1040; Ann Lindley, "The Early-Morning Phone Call: Remittances from a Refugee Diaspora Perspective," Journal of Ethnic and Migration Studies 35 (2009): 1315-1334; Dianna Shandy, "Global Transactions: Sudanese Refugees Sending Money Home," Refuge 23, no. 2 (2006): 28-36.

3. Statistics Canada, Census Snapshot-Immigration in Canada: A Portrait of the Foreign-Born Population, 2006 Census, accessed September 10, 2012, http://www.statcan.gc.ca/ pub/11-008-x/2008001/article/10556-eng.htm\#21

4. Louis-Jacques Dorais, Lise Pilon-Le, and Huy Nguyen, Exile in a Cold Land: A Vietnamese Community in Canada (New Haven, CT: Yale Southeast Asia Studies, 1987); Steven Gold, Refugee Communities: A Comparative Field Study (Newbury Park, CA: Sage, 1992).

5. Raul Hernández-Coss, “The Canada-Vietnam Remittance Corridor: Lessons on Shifting from Informal to Formal Transfer Systems" (World Bank Working Paper No. 48, World Bank, Washington, DC, 2005).

6. Bob Orr, "Resettlement: A Durable Solution," Canadian Issues, March 2004, 22-24.

7. Statistics Canada, Immigrant Status and Period of Immigration (8) and Place of Birth (261) for the Immigrants and Non-permanent Residents of Canada, Provinces, Territories, Census Metropolitan Areas and Census Agglomerations, 2006 Census-20\% Sample Data, accessed September 10, 2012, http://www5.statcan.gc.ca/bsolc/olc-cel/ olc-cel? catno=97-557-X\&chropg=1\&lang=eng.

8. Orr, "Resettlement: A Durable Solution."
9. Statistics Canada, Immigrant Status and Period of Immigration.

10. Don Locke, Increasing Multicultural Understanding (Newbury Park, CA: Sage, 1992).

11. Gold, Refugee Communities.

12. Dorais, Pilon-Le, and Nguyen, Exile in a Cold Land.

13. Rosalie Wieder, "Who Are the Vietnamese Americans?" in Asian American Almanac: A Reference Work on Asians in the United States, ed. S. Gall and I. Natividad (Detroit, MI: Gale Research, 1995), 165-174.

14. Hung Cam Thai, "Money and Masculinity among Low Wage Vietnamese Immigrants in Transnational Families," International Journal of Sociology of the Family 32 (2006): 247-271.

15. Hernández-Coss, The Canada-Vietnam Remittance Corridor.

16. Akuei, Remittances as Unforeseen Burdens.

17. Laura Simich, B.Khamisa Baya, Hayley Hamilton, and Gertrud Neuwirth, The Study of Sudanese Settlement in Ontario: Final Report, Citizenship and Immigration Canada, Settlement Directorate, Ontario (May 28, 2004), acessed September 18, 2012, http://atwork.settlement.org/downloads/ atwork/Study_of_Sudanese_Settlement_in_Ontario.pdf.

18. Johnson and Stoll, "Remittance Patterns of Southern Sudanese Refugee Men."

19. Lim, "'Loss of Connections is Death."

20. Jane Shakespeare-Finch and Kylie Wickham, "Adaptation of Sudanese Refugees in an Australian Context: Investigating Helps and Hindrances," International Migration 48 (2010): 23-44.

21. Kathrin Stoll and Phyllis Johnson, "Determinants of the Psychosocial Adjustment of Southern Sudanese Men," Journal of Refugee Studies 29 (2007): 621-640.

22. René Houle and Grant Schellenberg, "Remittances by Recent Immigrants," Perspectives, July 2008, 5-16.

23. Daniel Hiebert and David Ley, "Characteristics of Immigrant Transnationalism in Vancouver," in Transnational Identities and Practices in Canada, ed, V. Satzewich and L. Wong (Vancouver: University of British Columbia Press, 2006), 71-90.

24. Andrew Telegdi, "Family Reunification: The Key to Successful Integration," Canadian Issues: Immigration and Families, Spring 2006, 94-96.

25. Citizenship and Immigration Canada, Sponsoring your Family accessed January 2009, http://www.cic.gc.ca/ english/immigrate/sponsor/index.asp; Rell DeShaw, "The History of Family Reunification in Canada and Current Policy," Canadian Issues: Immigration and Families, Spring 2006, 9-14.

26. Phyllis Johnson, "Financial Responsibility for the Family: The Case of New Residents from Southeast Asia," Journal of Family and Economic Issues 24 (2003): 121-142.

27. John Knodel, "The Design and Analysis of Focus Group Studies: A Practice Approach," in Successful Focus Groups: Advancing the State of the Art, ed. D. L. Morgan (Newbury 
Park, CA: Sage, 1993), 35-50; Anselm Strauss and Juliet Corbin, Basics of Qualitative Research: Grounded Theory Procedures and Techniques (Newbury Park, CA: Sage, 1990).

28. Lim, "Loss of Connections is Death"'

29. Shakespeare-Finch, "Adaptation of Sudanese Refugees."

30. So-Leong Lim, "Loss of Connections is Death"; Shakespeare-Finch and Wickham, "Adaptation of Sudanese Refugees"; Stoll and Johnson, "Determinants of the Psychosocial Adjustment of Southern Sudanese Men."

31. Laura Simich et al., The Study of Sudanese Settlement; Shakespeare-Finch and Wickham, "Adaptation of Sudanese Refugees."

32. Orr, "Resettlement: A Durable Solution."

33. Citizenship and Immigration Canada, News Release-Government of Canada to Cut Backlog and Wait Times for Family Reunification-Phase I of Action Plan for Faster Family Reunification, accessed July 1, 2012, http://www.cic.gc.ca/ english/department/media/releases/2011/2011-11-04.asp.

34. Brooke Wilmsen, "Family Separation: The Policies, Procedures, and Consequences for Refugee Background Families," Refugee Survey Quarterly 30 (2011): 44-63. 35. Alan Simmons, Dwaine Plaza, and Victor Piché, The Remittance Sending Practices of Haitians and Jamaicans in Canada (CERLAC, York University, Toronto, 2005), accessed June 15, 2013, http://www.yorku.ca/cerlac/ documents/remittances.pdf.

36. Kathy Sherrell and Jennifer Hyndman, "Global Minds, Local Bodies: Kosovar Transnational Connections beyond British Columbia" (Working Paper Series No. 04-10, Vancouver Centre of Excellence: Research on Immigration and Integration in the Metropolis, Vancouver, BC, 2004), accessed June 15, 2013, http://mbc.metropolis.net/assets/ uploads/files/wp/2004/WP04-10.pdf.
37. Catherine Nolin, Transnational Ruptures; Gender-Enforced Migration. (Burlington, VT: Ashgate, 2006).

38. Alan Simmons, Immigration and Canada: Global and Transnational Perspectives (Toronto: Canadian Scholars' Press and Women's Press, 2010).

Phyllis Johnson (corresponding author; phyllis.johnson@ubc. ca) is in the Department of Sociology at the University of British Columbia. She is the author of the book Consumer Acculturation: Financial Issues of Immigrants and Refugees (Springer, forthcoming, anticipated publication date 2014). She was the 2011 recipient of the Jan Trost award from the National Council on Family Relations' International Section in recognition of her significant research contributions to cross-cultural family scholarship.

Kathrin Stoll has degrees in psychology and sociology, and recently completed an interdisciplinary $\mathrm{PhD}$ (midwifery/nursing/epidemiology) at the University of British Columbia. She has been active in academic and community based research for the past ten years with a focus on immigrant and refugee and maternity care issues. She is a postdoctoral fellow at the University of British Columbia and a part-time lecturer in the European Master's of Midwifery program.

Funding sources were the Margaret Speechly Stansfield Memorial Award from the Canadian Home Economics Foundation, and a UBC-Social Sciences and Humanities Research Council Small Grant.

(C) Phyllis J. Johnson and Kathrin Stoll, 2013. This open-access work is licensed under a Creative Commons Attribution-NonCommercial 4.0 International License, which permits use, reproduction and distribution in any medium for non-commercial purposes, provided the original author(s) are credited and the original publication in Refuge: Canada's Journal on Refugees is cited. 